\title{
A quarter century of liver transplantation: Learning from livers
}

PAUL C. ADAMS, MD

\begin{abstract}
Liver transplantation has emerged as a powerful tool to increase the understanding of physiological and pathophysiological processes in the liver. Transplantation for metabolic diseases with resolution of the disease process has been the ultimate proof of the hepatic source of the defect. Recurrence of the primary disease in the liver following transplantation has furthered understanding of the pathogenesis of hepatitis and the cell biology of hepatobiliary tumours. The role of genetics and immune factors in the pathogenesis of alcoholic liver disease may be clarified with the increasing numbers of patients transplanted for alcoholic cirrhosis. Normal gallbladder motility in the denervated transplanted liver questions the role of neuronal influences on gallbladder function. Finally, experimental liver transplantation in animals has been used as a tool to study metabolic problems. Can J Gastroenterol 1989;3(4):162-164
\end{abstract}

Key Words: Liver transplantation

\section{Un quart de siecle de transplantation du foie: Les leçons apprises}

RESUME: La greffe du foie s'est avérée un outil puissant pour améliorer notre compréhension des fonctions physiologiques et physiopathologiques du foie. La greffe effectuée dans le but de traiter les maladies métaboliques et qui se traduit par la résolution du processus morbide, est bien la preuve ultime de l'origine hépatique du problème. La reprise de la maladie primaire dans le foie après la transplantation nous permet de mieux connaître la pathogénèse de l'hépatite et la biologie cellulaire des tumeurs hépatobiliaires. Le rôle des facteurs génétiques et immunitaires dans la pathogénèse de la cirrhose de Laënnec peut être clarifié avec le nombre croissant de transplantés traités pour cirrhose alcoolique. La motilité normale de la vésicule biliaire dans le foie transplanté dénérve oblige à remettre en question le rôle des influences neuronales sur la fonction de la vésicule. Enfin, la greffe expérimentale du foie chez les animaux a servi d'instrument à l'étude des problèmes métaboliques.

University Hospital, University of Western Ontario, London, Ontario

Correspondence and reprints: Dr Paul Adams, Room 5-OF18, University Hospital, PO Box 5339, London, Ontario N6A 5A5. Telephone (519) 663-3513

Received for publication March 24, 1989. Accepted June 6, 1989
$T$ HE BENEFITS OF ORTHOTOPIC LIVER transplantation since its inception in humans in 1963 (1) have been enormous. Foremost, are the obvious benefits to the patient with previously untreatable end stage liver disease, who can now be offered a new lease on life following successful transplantation of the liver. The widespread use of liver transplantation has improved surgical and anesthetic techniques, im. munosuppressive protocols and methods of preservation. Liver transplantation in children has given liver research a boost by educating the public that cirrhosis is not restricted to the alcoholic patient. Liver transplantation has also made a significant contribution to the field of hepatology in that it has allowed us to understand in more detail many physiological and pathophysiological processes in the liver. In this review, some of these les. sons that have been learned from a quarter century of liver transplantation will be presented.

Liver transplantation to correct a congenital defect in metabolism that has originated in the liver has resulted in some spectacular cures of once fatal and untreatable diseases (2). Table 1 lists metabolic diseases which can be treated by liver transplantation. Type II 
TABLE I

\section{Metabolic diseases treated by liver transplantation}

Type II hypercholesterolemia (3)

Hemophilia A (4)

Hemophilia B (5)

Combined hemophilia $A$ and $B$

(unpublished data)

Primary hyperoxaluria (6)

Wilson's disease (7)

Tyrosinemia (8)

Crigler-Najjar syndrome I (9)

Protoporphyria (10)

Byler's disease (10)

Alphai-antitrypsin deficiency (11)

Glycogen storage diseases (12)

sea-blue histiocyte syndrome (13)

Niemann-Pick disease (14)

hypercholesterolemia is a condition which is caused by a lack of low density lipoprotein (LDL) receptors in the liver. In this condition the liver is histologically normal and the end organ is usually the heart with early coronary artery disease. Successful transplantation of the liver to restore the receptors to clear the lipids from the circulation along with transplantation of the damaged hequrt has resulted in a cure of this congenital condition (3). Similarly, the well known morbidity and mortality associated with hemophilia have been cured by liver transplantation $(4,5)$. This confirms that factor VIII coagulant activity, which is deficient in hemophilia, is dependent on the liver for significant production. Correction of the missing hepatic enzyme in primary hyperoxaluria by liver transplantation in conjunction with a renal transplant to correct the damaged organ is another example of a cure for a previously incurable disease (6).

These examples illustrate how orthotopic liver transplantation for a suspected hepatic defect is the ultimate proof of the original hypothesis for the pathogenesis of the disease. Wilson's disease, a congenital disorder in copper metabolism that results in copper overload in the liver and brain, can be cured by liver transplantation. Although many patients with Wilson's disease will not require transplantation because of lifelong treatment with copper chelating agents, some patients still present with refractory end stage liver disease, acute fulminant hepatic failure or disabling neurological deficits. Although a defect in hepatic biliary copper excretion was postulated, successful liver transplantation in these patients confirmed the hepatic basis for the disease, and the spectacular neurological recovery following transplantation in some patients $(7,15)$ suggested that the new liver could facilitate the clearance of residual copper from the central nervous system.

Another way in which liver transplantation has enhanced the understanding of basic liver diseases is by the observations on the recurrence of primary liver diseases following transplantation. Early reports suggested that primary biliary cirrhosis recurred following transplantation (16). However, because of the histological similarity between chronic graft rejection and primary biliary cirrhosis, it is most difficult to prove a recurrence of this disease. Recurrence of autoimmune chronic active hepatitis has been documented $(17,18)$. This raises the question of whether circulating antibodies interact with normal antigens in the new liver or alternatively may suggest a viral etiology to this condition. The persistence of antimitochondrial antibodies following liver transplantation in patients with primary biliary cirrhosis does not result in disease recurrence and suggests that this antibody is not directly involved in the pathogenesis of the disease. Hepatitis B will always recur in a transplanted patient but the clinical sequelae of the recurrence of viremia is unpredictable (19). This observation confirms that extrahepatic reservoirs of hepatitis B virus exist and long term follow-up of these immunosuppressed patients will add to the understanding of the complex interrelationship between hepatitis B virus and the immune system.

The recurrence of hepatic tumours following transplantation has been disappointing. Primary hepatocellular carcinoma has a recurrence rate of $70 \%$ at one year and cholangiocarcinoma has been reported to have a $100 \%$ recurrence rate $(15,20)$. Best results for tumours have been for the fibrolamellar variant of hepatocellular carcinoma and for microscopic tumours discovered incidentally following the removal of a cirrhotic liver (21). The observation that the transplanted liver can be the site of recurrence suggests that the residual malignant cells have a preference for the milieu provided by the hepatic microstructure. The high incidence of recurrent tumour also emphasizes the limitations of conventional screening procedures for metastatic disease prior to transplantation. The increased risk of malignancy in liver transplant patients on chronic immunosuppression has also illustrated the role of immunological surveillance in the development of neoplastic disease. In particular, the development of lymphoproliferative disease that regresses following cessation of immunosuppression (22) may have implications in the etiology of these conditions since viral markers have been found in a variety of lymphomas.

Recently, a large series of patients transplanted for alcoholic cirrhosis was reported (23). Although the authors have suggested that pre-selection of abstinent patients together with the ordeal of transplantation has resulted in a group of patients with no relapses to alcohol abuse, a skeptic would suggest that eventually some of these patients will return to alcohol use and abuse. Since the genetic aspects of susceptibility to alcohol have been emphasized (24) it will be of great interest to see if the transplanted liver will be injured by alcohol abuse. Furthermore, there has been evidence that both cell mediated and humoral immune factors may play a role in the pathogenesis of alcoholic liver disease $(25,26)$ and so the effects of long term immunosuppression will be of interest in the alcoholic transplant patient. As well as its role in helping to elucidate the pathogenesis of a number of liver diseases, liver transplantation has also clarified understanding of basic physiologic processes. For example, it has been traditional teaching that gallbladder contractility is regulated by neuronal influences and gastrointestinal hormones. The observation that the denervated gallbladder, which has been transplanted with the liver, 
responds normally to hormonal stimuli raises doubts about the relative importance of neurogenic stimuli (27). Furthermore, several transplant patients have suffered from biliary colic following the transplant (unpublished data). The pain pathways for the denervated gallbladder are not well understood.

Finally, with the advent of experimental animal liver transplantation the opportunity now exists to vary a parameter in the liver, independent of

ACKNOWLEDGEMENTS: The author acknowledges the advice and assistance of Drs C. Ghent, D. Grant and W. Wall, and the University Hospital Liver Transplant Team.

\section{REFERENCES}

1. Starzl TE, Marchioro TL, Von Kaulla $\mathrm{K}$, et al. Homotransplantation of the liver in humans. Surg Gynecol Obstet 1963;117:659-76.

2. Groth CG, Ringden O. Transplantation in relation to the treatment of inherited disease. Transplantation 1984:38:319-27.

3. Bilheimer DW, Goldstein JL, Grundy SM, et al. Liver transplantation to provide low density lipoprotein receptors and lower plasma cholesterol in a child with homologous familial hypercholesterolemia. N Engl J Med 1984;311:1658-64.

4. Bontempo FA, Lewis JH, Gonrenc T], et al. Liver transplantation in hemophilia A. Blood 1987;69:1721-4.

5. Merion RM, Delius RE, Campbell DA, et al. Orthotopic liver transplantation totally corrects factor IX deficiency in hemophilia B. Surgery 1988;104:929-31.

6. Watts RWE, Rolles K, Morgan SH, et al. Successful treatment of primary hyperoxaluria Type I by combined hepatic and renal transplantation. Lancet 1987;ii:474-5.

7. Beart RW, Putman LW, Porter KA. et al. Liver transplantation for Wilson's disease. Lancet 1975;ii:176-7.

8. Fisch RO, McCabe ER, Doeden D, et al. Homotransplantation of the liver in a patient with hepatoma in hereditary tyrosinemia. J Pediatr 1978;93:592-6.

9. Kaufman SS, Wood RP, Shaw BW, et al. Orthotopic liver transplantation for body influences, and measure the result in the recipient animal. For example, transplantation of an iron overloaded liver into a normal animal resulted in a marked reduction in iron absorption in the recipient animal particularly when the hepatocytes were preferentially loaded compared to the Kupffer cells (28). This experimental model allows an evaluation of the effect of hepatic iron on iron absorption independent of total body iron stores. Further applica- tions of experimental liver transplantation as a model to study metabolic problems are anticipated.

In conclusion, there have been many ways in which clinical and experimental liver transplantation have increased understanding of normal and abnormal liver function. The rapid in. crease in the use of orthotopic liver transplantation around the world will increase the rapidly growing knowledge base in hepatology.
Type I Crigler-Najjar syndrome. Hepatology 1986;6:1259-62.

10. Polson RJ, Williams R. Application to inborn errors of metabolism. In: Calne RY, ed. Liver Transplantation, 2nd edn. London: Grune and Stratton, 1987:77-89.

11. Putman CW, Porter KA, Peters RL, et al. Liver replacement for alpha-l-antitrypsin deficiency. Surgery 1977;81:258-61.

12. Malatack JJ, Finegold DN, Iwatsuki S, et al. Liver transplantation for type I glycogen storage disease. Lancet i983;i:1073-6.

13. Zitelli BJ, Malatack JJ, Gartner JC, et al. Orthotopic liver transplantation in children with hepatic-based metabolic disease. Transplant Proc 1983;15:1284-7.

14. Daloze P, Delvin EE, Glorieux FH, et al. Replacement therapy for inherited enzyme defiency: Liver orthotopic transplantation in Niemann-Pick disease Type A. Am J Med Genet 1977;1:221-39.

15. O'Grady J, Williams R. Long-term management, complications, and disease recurrence. In: Maddrey WC, ed. Transplantation of the Liver. New York: Elsevier Science Publishing Co Inc, 1988:143-65.

16. Neuberger J, Portmann B, MacDougall BR, et al. Recurrence of primary biliary cirrhosis after liver transplantation. N Engl J Med 1982;306:1-4.

17. VanThiel DH, Gavaler JS. Recurrent disease in patients with liver transplantation: When does it occur and how can we be sure? Hepatology 1987;7:181-3.

18. Portmann B, O'Grady J, Williams R. Disease recurrence following orthotopic liver transplantation. Transplant Proc 1986;18:134-41.

19. Demetris AJ, Jaffe R, Sheehan DG, et al. Recurrent hepatitis B in liver allograft recipients: Differentiation between viral hepatitis $B$ and rejection. Am J Parhol 1986;125:161-72.

20. Iwatsuki S, Gordon RD, Shaw BW. et al. Role of liver transplantation in cancer therapy. Ann Surg 1985;202:401-7.

21. Starzl TE, Iwatsuki S, Shaw BW, et al Treatment of fibrolamellar hepatoma with partial or total hepatectomy and transplantation of the liver. Surg Gynecol Obstet 1986;162:145-8.

22. Penn I. Lymphomas complicating liver transplantation. Transplant Proc 1983;15:2790-7.

23. Starzl TE, VanThiel DH, Iwatsuki S, et al. Orthotopic liver transplantation for alcoholic cirrhosis. JAMA $1988: 260: 2542-4$.

24. Vesell ES, Page JG, Passananti GI. Genetic and environmental factors affecting ethanol metabolism in man. Clin Pharmacol Ther 1971;12:192-201.

25. Cochrane AMG, Moussouros A, Portman B, et al. Lymphocyte cytotoxicity for isolated hepatocytes in alcoholic liver disease. Gastroenterology 1977;72:918-23.

26. Kanagasurdarum N, Kakumu S, Chen T, Leevy CM. Alcoholic hyalin antigen $(\mathrm{AHAg})$ and antibody (AHAb) in alcoholic hepatitis. Gastroenterology 1977;73:1368-73.

27. Engel Cl, Grant D, Wall W, et al. Function of the transplant gallbladder in liver recipients. Clin Invest Med 1988;11:C90. (Abst)

28. Adams PC, Reece AS, Powell LW, Halliday JW. Hepatic iron in the control of iron absorption in a rat liver transplantation model.

Transplantation 1989:48:19-21. 


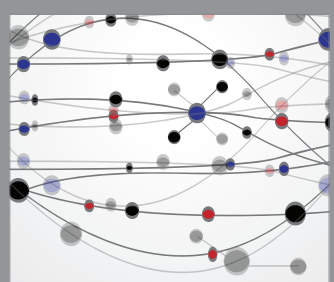

The Scientific World Journal
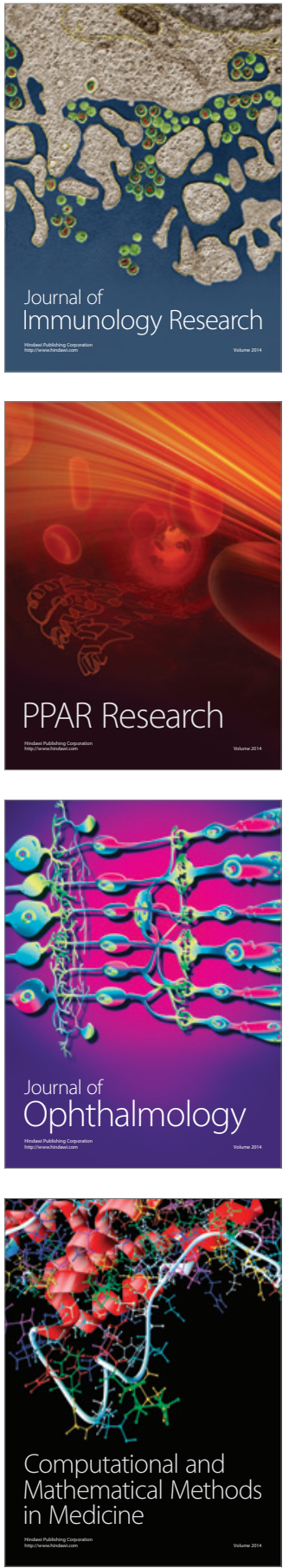

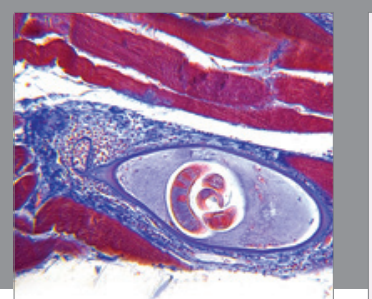

Gastroenterology Research and Practice

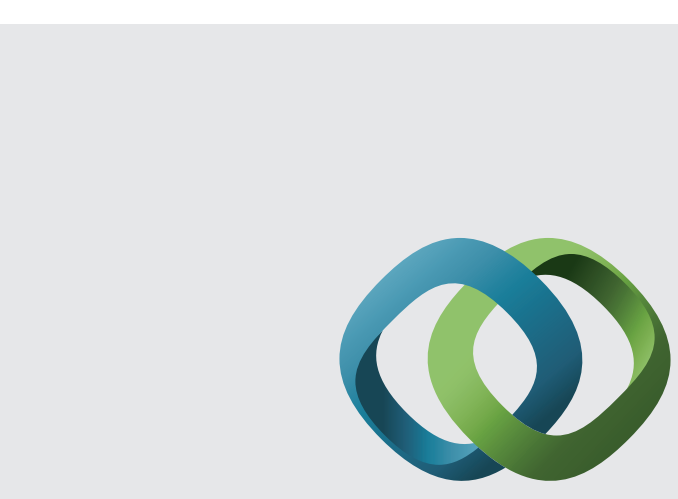

\section{Hindawi}

Submit your manuscripts at

http://www.hindawi.com
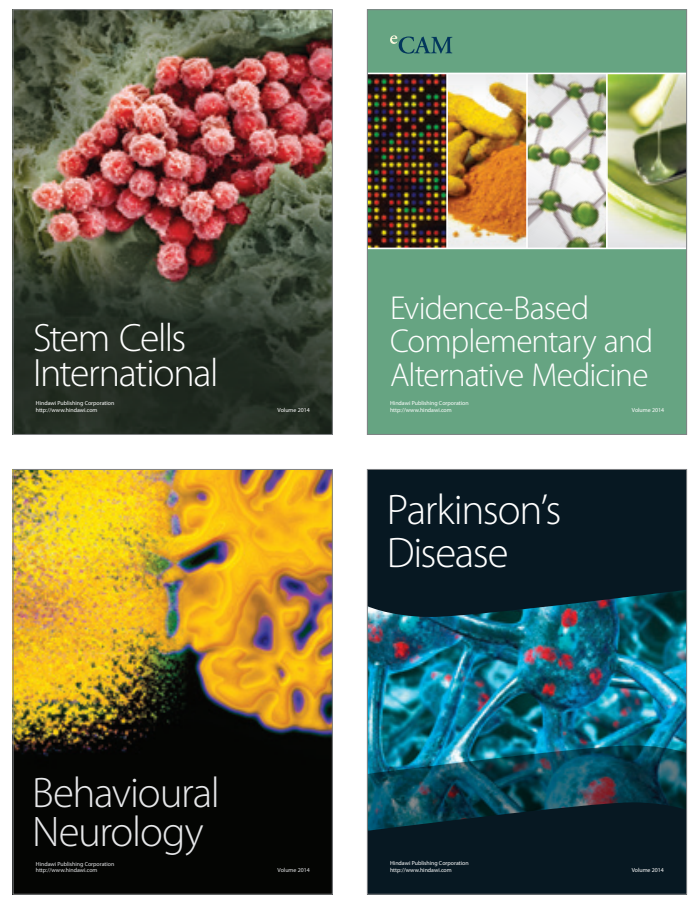
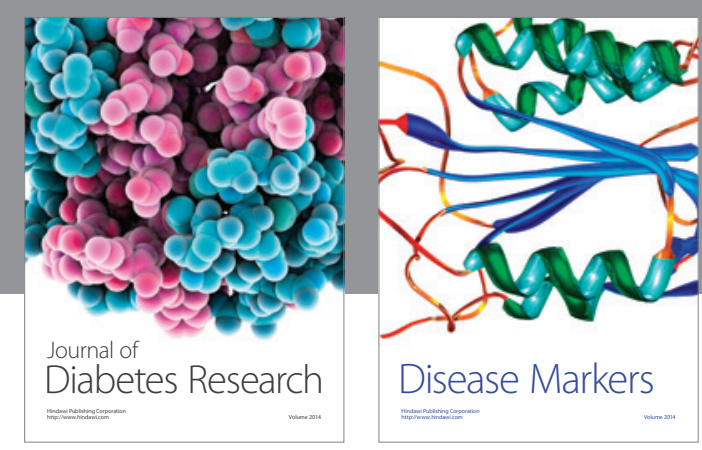

Disease Markers
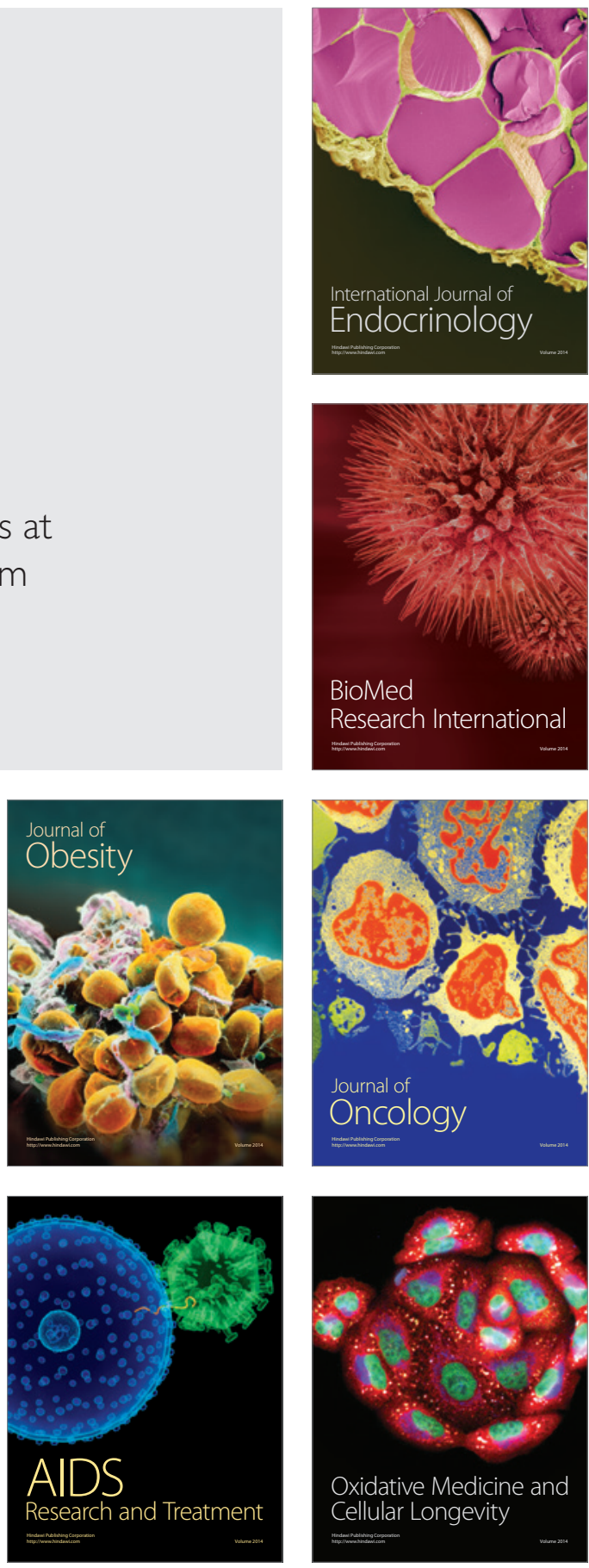